\title{
Learning from 8 years of regional cyanobacteria observation in Brittany in view of sanitary survey improvement
}

\author{
Frédéric Pitois ${ }^{a}$, Olivier Thom as ${ }^{b, c}$, Isabelle Thor aval ${ }^{a}$, Estelle Baurès ${ }^{b, c^{*}}$ \\ ${ }^{a}$ Limnology, 16 rue Paul Langevin, 35200 Rennes, France \\ ${ }^{b}$ EHESP Rennes, Sorbonne Paris G té, Avenue du Professeur Léon Bemard- CS 74312, 35043 Rennes Cedex, France \\ ${ }^{c}$ Inserm, U 1085-IRSET, LERES, France
}

\begin{abstract}
*Corresponding author: Estelle Baurès, estelle.baures@ehesp.fr, + (33) (0) 299022919
Keywords: cyanobacteria; monitoring; water quality; microcystins; regional scale.
\end{abstract}

\begin{abstract}
Cyanobacteria and cyanotoxins have been more and more studied during the last decades with regard to environment and health issues. More recently the consequences of climate change reinforced the need for research in view of a better management of cyanobacteria blooms. In this context the exploitation of the water quality survey of 26 recreational lakes in Brittany (north western France) between 2004 and 2011 is reported in this paper in order to encompass spatial and interannual patterns of cyanobacteria development at a regional scale. Starting from weekly data principally acquired during summertime, the links between cyanobacteria cell densities, toxin occurrences and interannual meteorological factors can give insights on the potential evolution of cyanobacterial crisis in the future. This study is part of a project aiming at a better understanding of potentially toxic cyanobacteria crisis occurrences in recreational waters, in order to improve predictive monitoring routines.
\end{abstract}

\section{1- Introduction}

Since their appearance in the public health debate (Chorus and Bartram, 1999; Falconer, 1996), cyanobacteria and their toxins have gradually become a major concern for public health authorities. Several literature reviews focusing on toxin production were regularly published for the last 10 years, showing that biosynthetic pathways and toxicological issues are relatively well known (Leflaive and Ten-Hage, 2007; Smith et al., 2008; Araoz et al., 2010; Pearson et al., 2010). Among scientific questions remaining unsolved, there is no evidence of any direct relation between cyanobacterial biomass and toxin concentration, nor any consensus on toxin ecological role in the cyanobacterial cell life cycle. This lack of knowledge of toxin causality and of understanding of toxin purpose 
prevents any attempt in the prediction of algae blooms risk occurrence. The relations between cyanobacterial biomass and trophic enrichment (eutrophication processes) are widely admitted, whereas the influence of meteorological parameters on in situ algal growth is less discussed. Some abiotic parameters have nevertheless been studied in vitro in terms of selection and growth rates of potentially toxic species (De Nobel et al., 1998; Baker and Bellifemine, 2000; Hadas et al., 2002; McCausland et al., 2005; Yamamoto and Nakahara, 2005; Imai et al., 2009) and through their influence on toxin biosynthesis (Rapala and Sivonen, 1998; Wiedner et al., 2003; Tonk et al., 2005; Briand et al., 2008; Preussel et al., 2009). Reports of in vitro influence of light and temperature on cyanobacterial growth and toxin production emphasize the possible consequences of dimate change on public health concerns regarding bathing and water resources for drinking water production. Exploring the relations between in situ abiotic factors, climate change consequences, cyanobacteria distribution and public health parameters at a regional scale is the main objective of this research, based on the analysis of monitoring data collected by local health authorities since 2004 in Brittany (France). This study intends to enlighten some aspects of the interannual dynamics of cyanobacterial development in 26 lakes used as recreative waters, and is directed toward the development of risk indices predictive of cyanobacteria-associated crisis. 


\section{2- Material and method}

Our study is based on public health weekly survey data from 26 recreational lakes monitored every year from 2004 to 2011 in Brittany (north-western France, Figure 1).

See Appendix for Figure 1

Table 1 gives some characteristics of these 26 sites.

See Appendix for Table 1

Cyanobacteria data, i.e. cell densities, species composition and microcystin concentrations, were collected from the regional public health authorities (French Agence Régionale de Santé (ARS) of Brittany). Hydrology and lake morphology parameters (i.e. depth, lake volume, watershed area... ) were gathered from dedicated institutional databanks held by the Ministry for the Environment (BDHydro) and Agence de l'Eau Loire-Bretagne (OsurWeb), or directly from lake owners.

In addition, monthly meteorological data (precipitation rates, temperature, sunshine hours...) were collected from Meteo France database (Climathèque) between 2001 and 2011.

For this study, correlations between parameters were calculated using the Pearson test. 


\section{3- Results}

\section{1- Meteorological context}

In the context of the last ten years, the oceanic climate appeared unstable during summer in Brittany. From 2001 to 2011, in spite of high interannual variability, available data (Figure 2) show a common tendency to decrease for mean temperatures (with a loss of nearly $\left.1^{\circ} \mathrm{C}\right)$, sunshine hours $(-7$ $\%$ ) and global radiations (- $4 \%$ ), whereas cumulated pluviometry increased by $+5 \%$.

See Appendix for Figure 2

\section{2 - Cyanobacteria cell densities}

First it can be noted that from 2004 to 2011 (i.e. the monitoring timespan), weekly maximal cyanobacteria cell densities tended to decrease (Figure 3a), although the opposite could be expected in a context of global warming. In the same time however, alert levels exceeding frequencies (Figure $3 b$ ) increased from 31 to $55 \%$ for WHO alert level 2 (20 $000 \mathrm{cell} / \mathrm{ml}$ ) and 13 to $27 \%$ for WHO alert level 3 (100 000 cell/ml).

See Appendix for Figure 3

This evolution seems to follow a gradual shift of frequency distribution (Figure 4) characterized on one hand, by a slow increase of background noise cell densities, as the 10th percentile (Q10) increases by a factor 2.5 , and, on the other hand, by a faster increase of median cell densities, as the median (Q50) increases by 5.5. In the same time, maximal cell densities (90th percentile: Q90) only increased by 1.5 .

\section{See Appendix for Figure 4}

For the same period, (from 2004 to 2011, June to September) WHO level 2 exceeding frequency followed a continuous +2 to +4 week/year increase (Figure $5 a$ ). In the same time, WHO level 3 exceeding frequency tended to increase by +1 to +2 week/year from June to July, moving to +3 week/year in August and September. Cell densities appeared to follow the same evolution as WHO level frequencies (Figure 5b), with at first a slow increase rate $\left(+2000\right.$ cell. $\left.\mathrm{ml}^{-1} \cdot \mathrm{yr}^{-1}\right)$ in June and July,

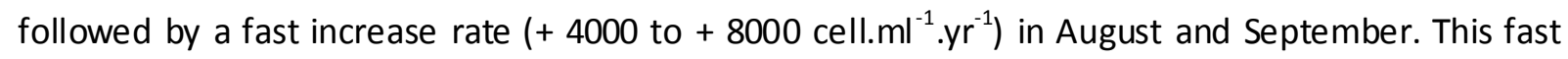
increase can explain why cell densities exceeding the WHO level 3 are observed earlier with time.

See Appendix for Figure 5

\section{3- Microcystins}

In spite of the high observation frequency of cell densities higher than the level 3 WHO thresholds, only $30 \%$ of the analysed samples hosted quantifiable microcystin concentrations, MCs (Figure 6a). It should be noted that detection frequency was inversely related to cell density, with a maximum of 33 
$\%$ for cell densities ranging from 10 to $20000 \mathrm{cell} / \mathrm{mL}$, compared to $15 \%$ for cell densities higher than $1000000 \mathrm{cell} / \mathrm{mL}$ (Figure 6b).

\author{
See Appendix for Figure 6
}

MCs detection frequencies could not be correlated to lake morphology, neither to watershed characteristics (data not shown). Detection frequencies, on the other hand, appeared to be correlated to summer meteorological parameters such as mean temperatures $(r=0.52)$ or cumulated sunshine hours and global radiation $(r=0.68$ and 0.69 respectively, $p<0.05)$. Surprisingly, frequencies could be negatively correlated to sunshine and global radiation of the previous winter $(r$ $=-0.54$ to -0.61$)$, but with a lower significance $(p<0.1)$. This could mean that MCs are more likely to be detected at the regional scale during years combining low winter sunshine and a high summer sunshine (it must be noted that winter and summer sunshine are not correlated).

\title{
3.4- Regional patterns
}

For each site, annual maximal cell densities and exposure duration (expressed as week number with cell density > 100000 cell/ml) were positively linked (Figure 7).

\section{See Appendix for Figure 7}

The cell density-exposure duration slope varies on an annual basis, and ranges from 98000 to 280 $000 \mathrm{cell} / \mathrm{mL}$ per exceeding week. The annual slope values appear correlated with mean annual summer temperature $(r=0.86)$, mean cumulated summer sunshine hours $(r=0.71)$ or cumulated global radiation $(r=0.69$ ). Surprisingly the slope is also negatively correlated with previous winter conditions such as sunshine hours $(r=-0.68)$, global radiation $(r=-0.58)$ and temperature $(r=-0.55)$. The winter sunshine/radiation parameters are not correlated with the next summer sunshine/radiation parameters. At the regional scale, these parameters combination can be translated into years with higher cell densities (weak winter light and high summer light) or longer exposure durations (high winter light and weak summer light).

Whatever the meteorological variations, an interannual recurrence relation can be highlighted. For each site, the annual exposure duration (i.e. number of weeks > level 3 WHO threshold) increases with the interannual frequency of cell density above WHO level 3 observations, whatever the duration of these exceedance episodes (Figure 8). This increase is observed for all sites where exceedance episodes were recorded at least 5 years out of 8 , corresponding to $50 \%$ of the survey period. The mean annual exposure duration increases from $2+/-1.6$ weeks if recurrence is less than $50 \%$ to a maximum of $7.5+/-4.4$ weeks for the sites with recurrence higher than $80 \%$. By definition, a higher recurrence is independent from meteorological interannual variations. Recurrence index then appears correlated with lake morphological parameters such as maximal depth $(r=-0.62)$ and watershed area $(r=-0.56)$. These relations are statistically significant $(p<0.01)$ but correlation coefficients are relatively low, indicating that supplementary parameters, still not identified, should be considered. The addition of both negative relations with depth and watershed area points out that shallower lakes with relatively smaller watersheds are more likely to experience interannually frequent, longer-lasting blooms. In this case, higher cyanobacteria cell densities (as duration and density parameters are correlated) will be recorded whereas MCs detection should be less frequent. 
See Appendix for Figure 8

\section{5- Discussion}

Many studies hypothesized that in the current climate change context, cyanobacteria should be more competitive than other species, leading to better dominance opportunities (Paerl and Otten, 2013; Carey et al., 2012; Kosten et al., 2012; O'Neil et al., 2012). The effect of climatic parameters however can be difficult to generalize, especially in lakes covering different ranges of depth, volume and nutrient loads, but it is likely that shallow unstratified lakes (the most common lake type in Brittany) should be the most responsive to global warming and the most affected by cyanobacteria extension (Malmaeus et al., 2006; Mooij et al., 2007; 2009). It must be noted that since the second half of 20th century, western France is experiencing a slight rise of annual mean temperatures and precipitations, with projected summer temperature increase and summer precipitation decrease (Terray and Boé, 2013). In the case of our study however, at the regional scale of Brittany, climate parameters follow a tendency to a slight decrease of summer temperature and sunshine conjugated with an increase of precipitations.

Long term studies of field data are still scarce in the literature. They all tend however to point out the strong influence of summer meteorological parameters on cyanobacterial populations, through light availability (Noges et al., 2003), water temperatures (Wiedner et al., 2007; Liu et al., 2011), or a combination of water temperature and sunshine hours (Zhang et al., 2012). While species-specific data cannot be easily extrapolated to population level, this could be expected in view of the many studies exploring temperature and light influence on cyanobacterial growth rate (De Nobel et al., 1999; Baker and Bellifemine, 2000; Hadas et al., 2002; Mac Causland et al., 2005; Yamamoto and Nakahara, 2005; Imai et al., 2009).

From 2004 to 2011, meteorology in Brittany followed an evolution opposite to predictions, but the analysis of survey data shows nevertheless a strong tendency to a continuous increase of cyanobacterial presence at the regional scale. This can be related to an increase of background noise more than maximal biomasses, leading to a longer lasting presence of relatively lower cell densities, rather than a higher frequency of 'classical' bloom episodes with high turbidity and floating cyanobacterial scum.

Our results can be compared to the conclusions of former studies carried out by Wiedner et al. (2007) and Rücker et al. (2009) emphasizing the influence of increasing winter temperatures on earlier akinete germination, this earlier germination leading to a faster growth of $\mathrm{C}$. raciborskii populations in spring. This principle of a larger inoculum influence on growth parameter seems to be relevant at the population level and regional scale, and can be illustrated by the correlations between winter meteorology (namely temperatures and sunshine hours) and cell density vs. exposure duration slope summarized in Table 2. At regional scale, higher winter temperatures can lead to a larger spring inoculum and high median cell densities even if summer temperature and sunshine are too low to favor higher biomasses.

See Appendix for Table 2 


\section{6- Conclusion}

This first study of eight years (from 2004 to 2011) of sanitary survey, annually during 16 weeks, shows that there is a strong homogeneity, at the regional scale, between parameters related to cyanobacteria cell densities and toxin detection frequency:

- The exposition pathways to cyanobacteria (cell density, WHO thresholds exceeding duration) and the exposition frequency (interannual recurrence of WHO thresholds exceeding episodes) are correlated and sites with higher cell density will tend to suffer longer proliferation episodes with a higher interannual frequency.

- Microcystins (MCs) detection is inversely correlated with exposure durations and cell densities: MCs detection frequency is higher when cell densities are lower, i.e. namely in the lakes where proliferation episodes are less frequent. As toxin monitoring was carried out with different analytical methods, it is impossible to correlate MCs detection frequencies and concentrations.

- The factors controlling users exposure pathways to cyanobacterial biomass and toxins appear to derive in the same time from lake morphology (interannual recurrence) and regional-scale meteorology (exposition duration, cell density, MCs detection frequency). However the lack of nutrient data for most lakes prevented us from assessing the trophic status influence on cyanobacterial parameters.

- The influence of lake morphology (volume, depth, watershed surface are interannual constants) and of winter meteorological parameters (sunshine, radiation) allows to consider the development of a simple model for annual risk characterization. In this case, potential risk would be evaluated before the beginning of summer sanitary surveys, indicating which exposure pathway should be emphasized (biomass and/or MCs).

- MCs detection frequencies are higher when cell densities are lower. This indicates that MCs monitoring should be extended to lakes where cyanobacteria are less visible, while toxin analysis are currently focused on higher cell density episodes.

\section{Aknowledgements}

This work is part of the ORACLE project funded by the French National Agency of Sanitary Security (ANSES) under the national program of Environment-Health-Work research (PNRSET 2012). The authors sincerely thank the French Agence Régionale de Santé (ARS) of Brittany and the French Agence de l'Eau Loire-Bretagne (AELB) for the data provided and are grateful to Caroline Farenc, student at the School of Environmental Engineering (EME), for the data exploitation.

\section{References}

Aráoz, R., Molgó, J., Tandeau de Marsac, N., 2010. Neurotoxic cyanobacterial toxins. Toxicon, 56(5), 813-828. 
Baker, P. D., Bellifemine, D., 2000. Environmental influences on akinete germination of Anabaena circinalis and implications for management of cyanobacterial blooms. Hydrobiologia 427(1), 65-73.

Briand, E., Yéprémian, C., Humbert, J-F., Quiblier, C., 2008. Competition between microcystin- and non-microcystin-producing Planktothrix agardhii (cyanobacteria) strains under different environmental conditions. Environ. Microbiol. 10(12), 3337-3348.

Carey, C. C., Ibelings, B. W., Hoffmann, E. P., Hamilton, D. P., Brookes, J. D., 2012. Eco-physiological adaptations that favour freshwater cyanobacteria in a changing climate. Water Res. 46(5), 13941407.

Chorus, I., Bartram, J., 1999. Toxic cyanobacteria in water: a guide to their public health consequences, monitoring and management, Spon Press, London \& New York.

De Nobel, W.T., Matthijs, H.C.P., Von Elert, E., Mur, L.R., 1998. Comparison of the light-limited growth of the nitrogen-fixing cyanobacteria Anabaena and Aphanizomenon, New Phytol. 138, 579587.

Falconer, I. R., 1996. Potential impact on human health of toxic cyanobacteria. Phycologia 35(6S), 611.

Hadas, O., Pinkas, R., Malinsky-Rushansky, N., Shalev-Alon, G., Delphine, E., Bemer, T., Sukenik, A., Kaplan, A., 2002. Physiological variables determined under laboratory conditions may explain the bloom of Aphanizomenon ovalisporum in Lake Kinneret. Eur. J. Phycol. 37, 259-267.

Imai, H., Chang, K-H., Kusaba, M., Nakano, S-I., 2009. Temperature-dependent dominance of Microcystis (Cyanophyceae) species: M. aeruginosa and M. weisenbergii. J. Plankton Res. 31, 171178.

Kosten, S., Huszar, V. L, Becares, E., Costa, L. S., Donk, E., Hansson, L. A., Scheffer, M., 2012. Warmer climates boost cyanobacterial dominance in shallow lakes. Glob. Change Biol. 18(1), 118-126.

Leflaive, J., Ten-Hage, L., 2007. Algal and cyanobacterial secondary metabolites in freshwaters: a comparison of allelopathic compounds and toxins. Freshwater Biol. 52(2), 199-214.

Liu, X., Lu, X., Chen, Y., 2011. The effects of temperature and nutrient ratios on Microcystis blooms inLake Taihu, China: An 11-year investigation. Harmful Algae 10, 337-343.

McCausland, M., Thompson, P., Blackburn, S. I., 2005. Ecophysiological influence of light and mixing on Anabaena circinalis (Nostocales, Cyanobacteria). Eur. J. Phycol. 40(1), 9-20.

Malmaeus, J. M., Blenckner, T., Markensten, H., \& Persson, I., 2006. Lake phosphorus dynamics and climate warming: A mechanistic model approach. Ecol. Model. 190(1), 1-14.

Mooij, W. M., De Senerpont Domis, L. N., Janse, J. H., 2009. Linking species- and ecosystem-level impacts of climate change in lakes with a complex and a minimal model. Ecol. Model. 220(21), 30113020. 
Mooij, W. M., Janse, J. H., De Senerponts Domis, L. N., Hülsmann, S., Ibelings, B. W., 2007. Predicting the effect of climate change on temperate shallow lakes with the ecosystem model PCLake. Hydrobiologia 584, 443-454.

Nõges, P., Tuvikene, L., Feldmann, T., Tõnno, I., Künnap, H., Luup, H., Nõges, T., 2003. The role of charophytes in increasing water transparency: a case study of two shallow lakes in Estonia. Hydrobiologia 506(1-3), 567-573.

O'Neil, J. M., Davis, T. W., Burford, M. A., Gobler, C. J., 2012. The rise of harmful cyanobacteria blooms: The potential roles of eutrophication and climate change. Harmful Algae 14, 313-334.

Paerl, H. W., Otten, T. G., 2013. Harmful cyanobacterial blooms: causes, consequences, and controls. Microbial ecol. 65(4), 1-16.

Pearson, L, Mihali, T., Moffitt, M., Kellmann, R., Neilan, B., 2010. On the chemistry, toxicology and genetics of the cyanobacterial toxins, microcystin, nodularin, saxitoxin and cylindrospermopsin. Marine drugs 8(5), 1650-1680.

Preußel, K., Wessel, G., Fastner, J., Chorus, I., 2009. Response of cylindrospermopsin production and release in aphanizomenon flos-aquae (cyanobacteria) to varying light and temperature conditions. Harmful Algae 8(5), 645-650.

Rapala, J., Sivonen, K., 1998. Assessment of environmental conditions that favor hepatotoxic and neurotoxic Anabaena spp. strains cultured under light limitation at different temperatures. Microbial Ecol. 36(2), 181-192.

Rücker, J., Tingwey, E. I., Wiedner, C., Anu, C. M., Nixdorf, B., 2009. Impact of the inoculum size on the population of Nostocales cyanobacteria in a temperate lake. J. Plankton Res. 31(10), 1151-1159.

Smith J.L, Boyer G.L., Zimba P.V., 2008. A review of Cyanobacterial odorous and bioactive metabolites: impacts and management alternatives in aquaculture. Aquaculture 280, 5-20.

Terray, L., Boé, J., 2013. Quantifying 21st-century France climate change and related uncertainties. Geoscience 345(3), 136-149.

Tonk, L., Visser, P. M., Christiansen, G., Dittmann, E., Snelder, E. O., Wiedner, C., Huisman, J., 2005. The microcystin composition of the cyanobacterium Planktothrix agardhii changes toward a more toxic variant with increasing light intensity. Appl. Environ. Microb. 71(9), 5177-5181.

Wiedner, C., Rücker, J., Brüggemann, R., \& Nixdorf, B., 2007. Climate change affects timing and size of populations of an invasive cyanobacterium in temperate regions. Oecologia 152(3), 473-484.

Wiedner, C., Visser, P. M., Fastner, J., Metcalf, J. S., Codd, G. A., Mur, L. R., 2003. Effects of Light on the Microcystin Content of Microcystis Strain PCC 7806. Appl. Environ. Microb. 69(3), 1475-1481.

Yamamoto, Y., Nakahara, H., 2005. The formation and degradation of cyanobacterium Aphanizomenon flos-aquae blooms: the importance of $\mathrm{pH}$, water temperature, and day length. Limnol. 6(1), 1-6. 
Zhang, M., Duan, H., Shi, X., Yu, Y., Kong, F., 2012. Contributions of meteorology to the phenology of cyanobacterial blooms: implications for future climate change. Water Res. 46(2), 442-452.

\section{Captions}

Figure 1: Spatial distribution of the 26 investigated sites in Brittany

Table 1: Characteristics of the 26 investigated sites

Figure 2: Meteorological data in Brittany, from 2001 to 2011, June to September: mean temperatures ( $n=33$ sites), cumulated pluviometry ( $n=34$ sites), cumulated sunshine hours ( $n=18$ sites) and cumulated global radiation ( $\mathrm{n}=21$ sites).

Figure 3: (a, left) Weekly maximal cell density evolution, from 2004 to 2011, June to September (1 dot $=1$ week), (b, right) Annual WHO level exceeding frequency, from 2004 to 2011, June to September

Figure 4: Cyanobacteria cell density percentile (Q10, Q50 and Q90) evolution from 2004 to 2011, June to September

Figure 5- Cyanobacteria density evolution from 2004 to 2011, June to September, for weeks 1 to 16 of the monitoring course: (a, left) WHO levels 2 and 3 frequency increase rate, (b, right) Median cell density increase rate

Figure 6: (a, left) Microcystin concentrations (MCs) frequency distribution, (b, right) Detection frequency vs. cell density. From 2004 to 2011, June to September

Figure 7: Relation between annual maximal cyanobacteria cell density and exposure duration (number of weeks > level 3 WHO threshold, 1 dot = 1 lake), from 2004 to 2011, June to September

Figure 8: Relation between years with level 3 WHO threshold observation and annual exposure duration, from 2004 to 2011, June to September

Table 2: Meteorological influence on cyanobacteria parameters 
Figure 1

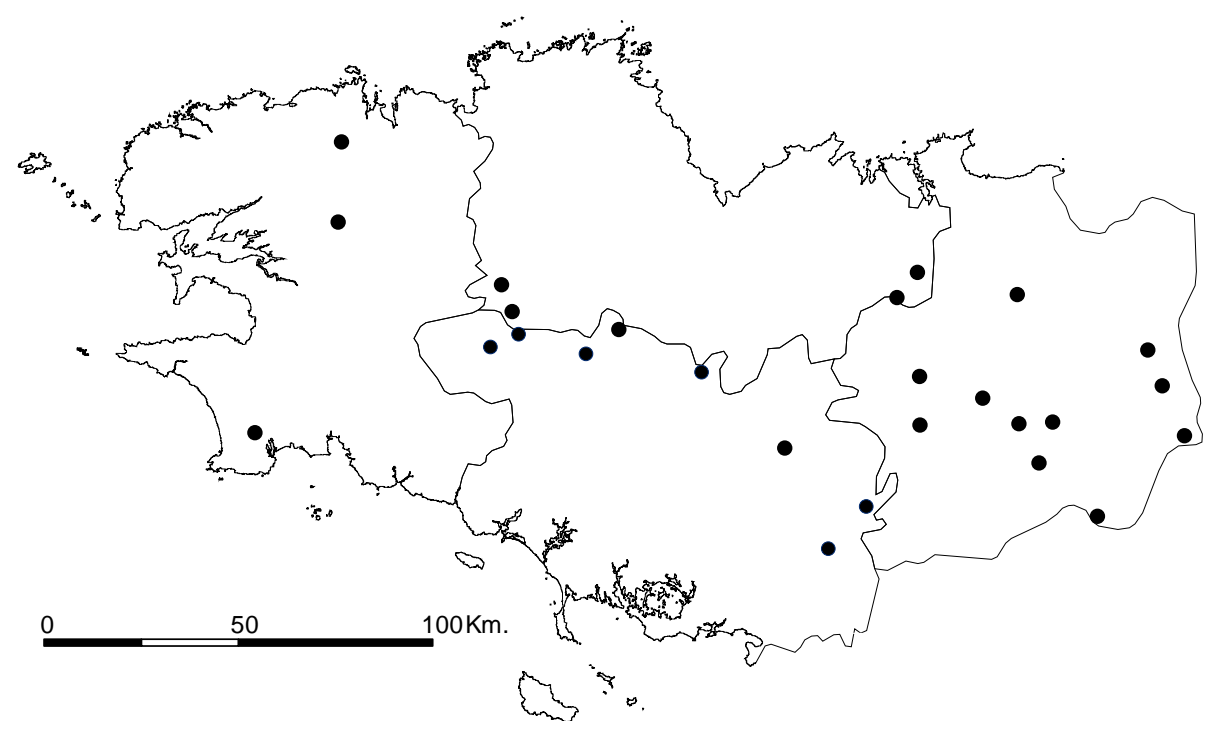

Figure 2

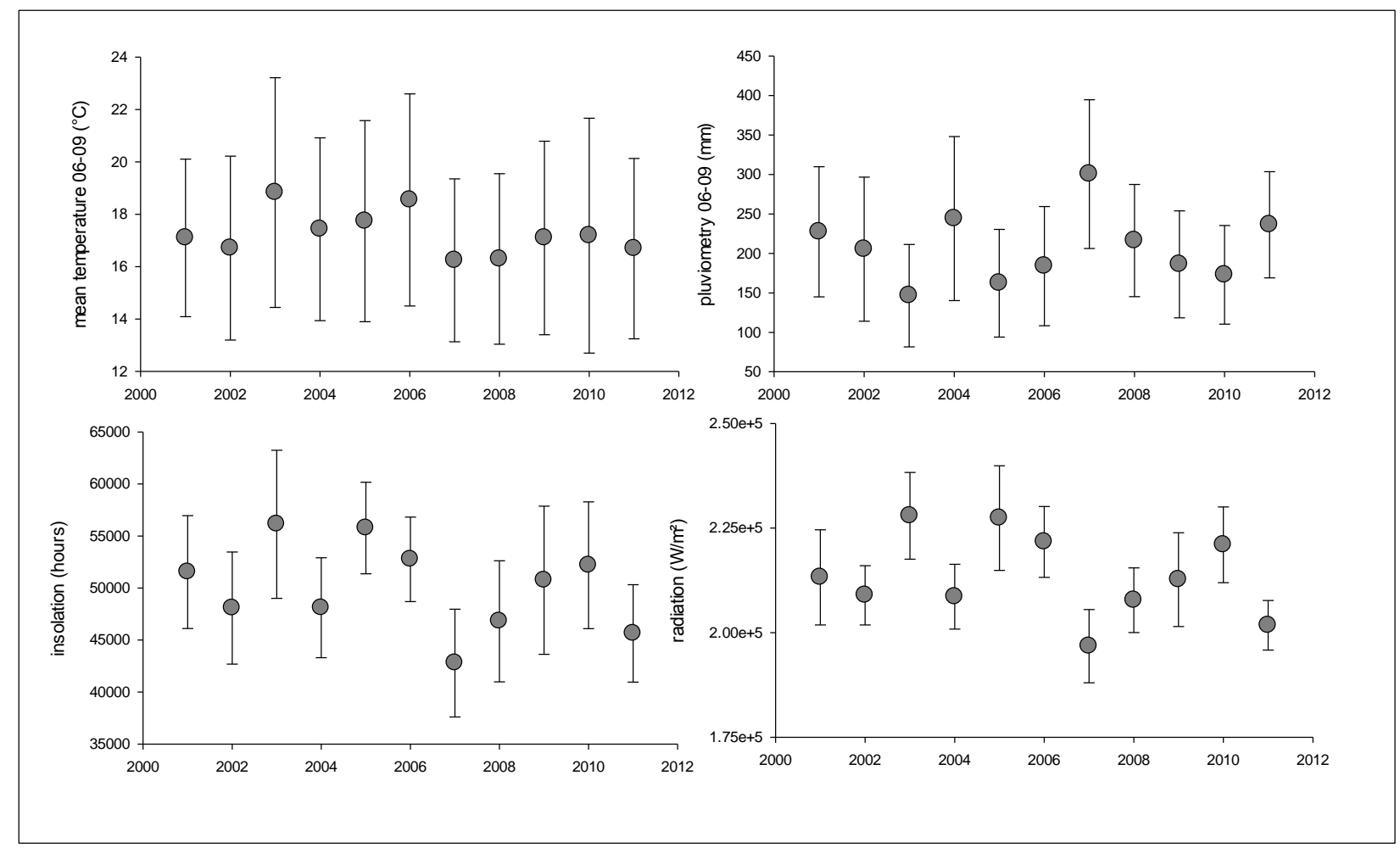


Figure 3
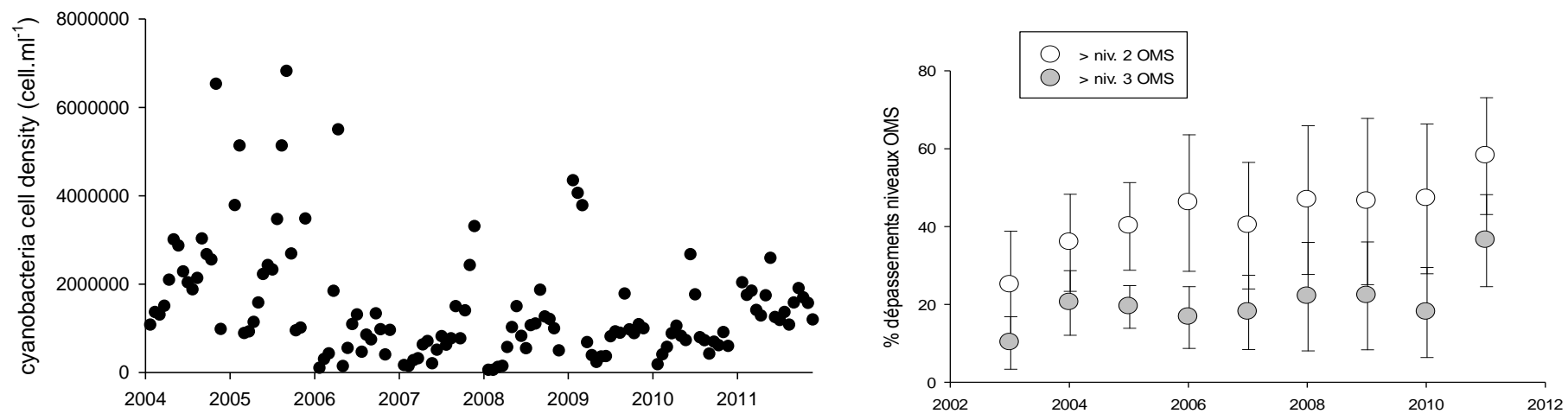

Figure 4

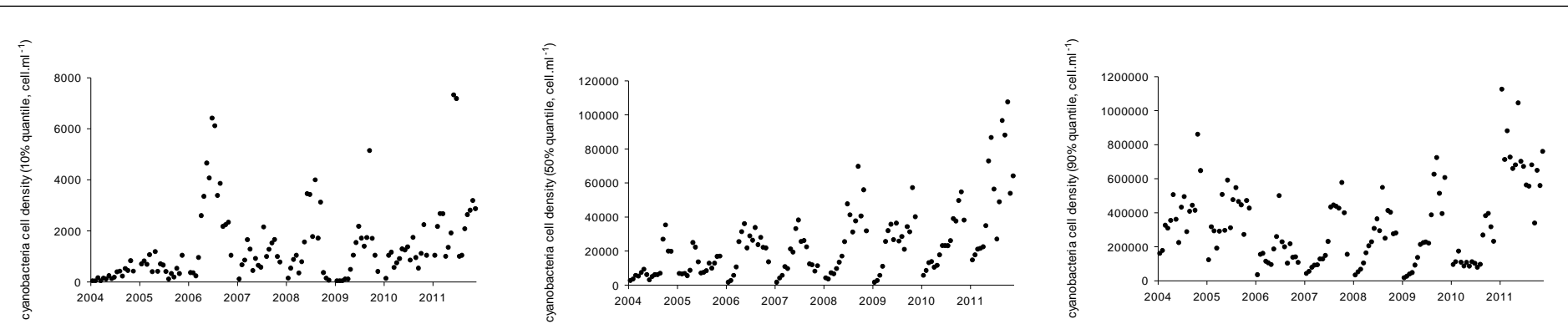

Figure 5
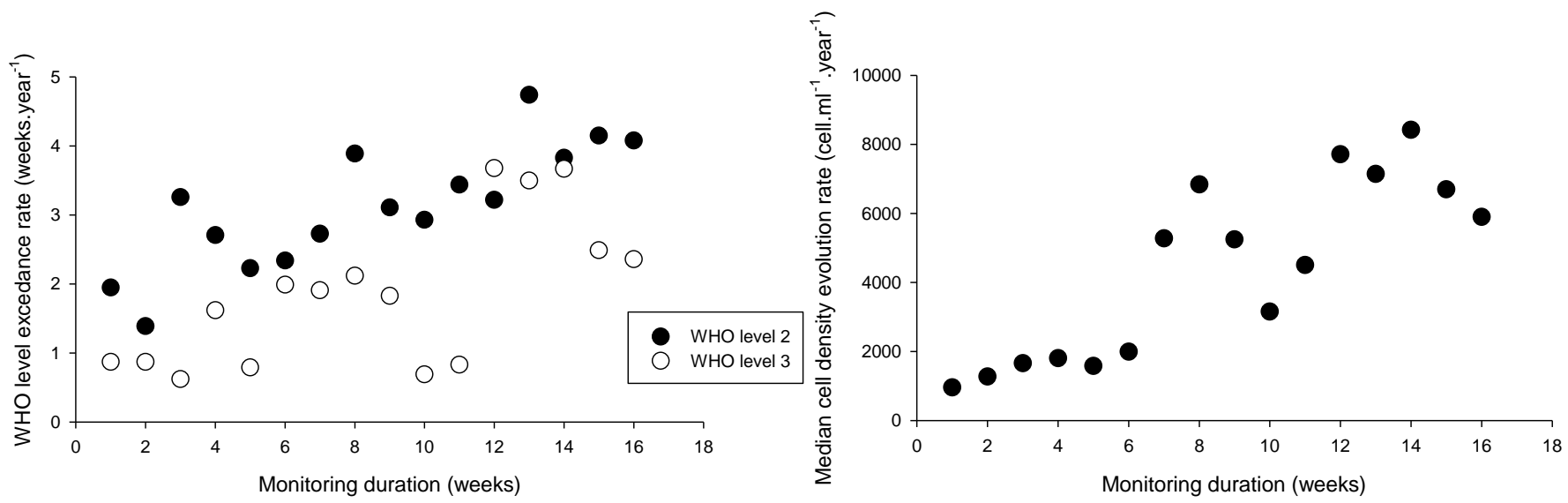
Figure 6
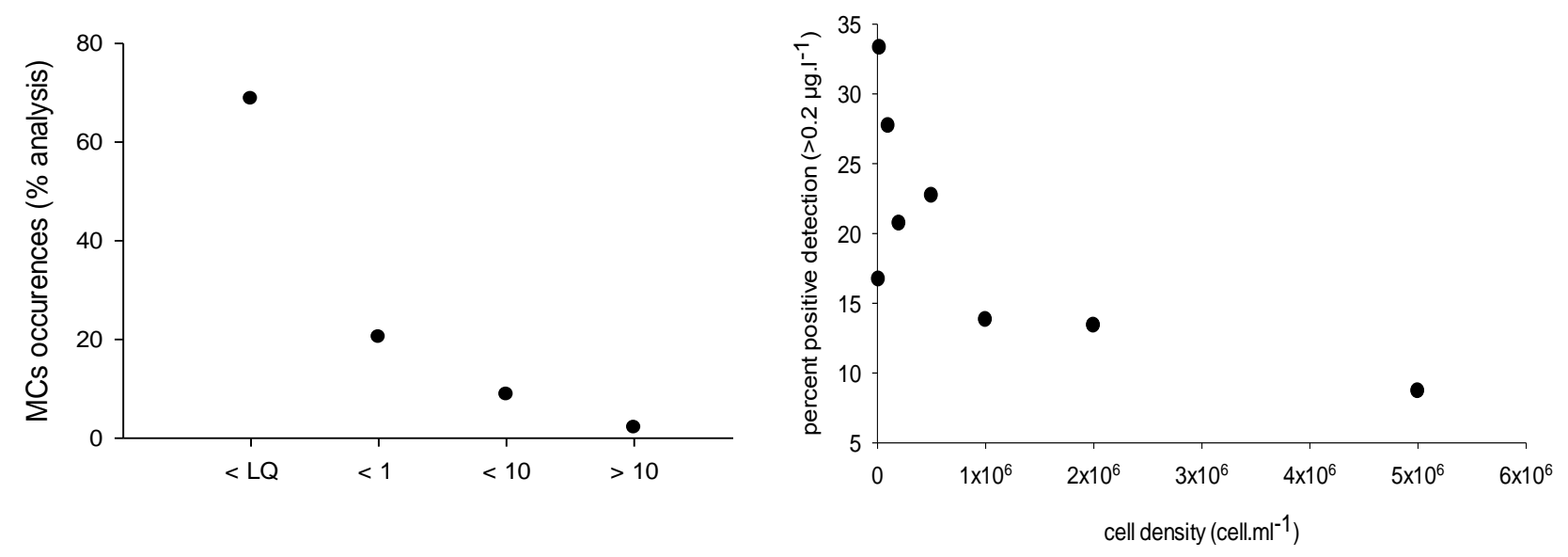

Figure 7

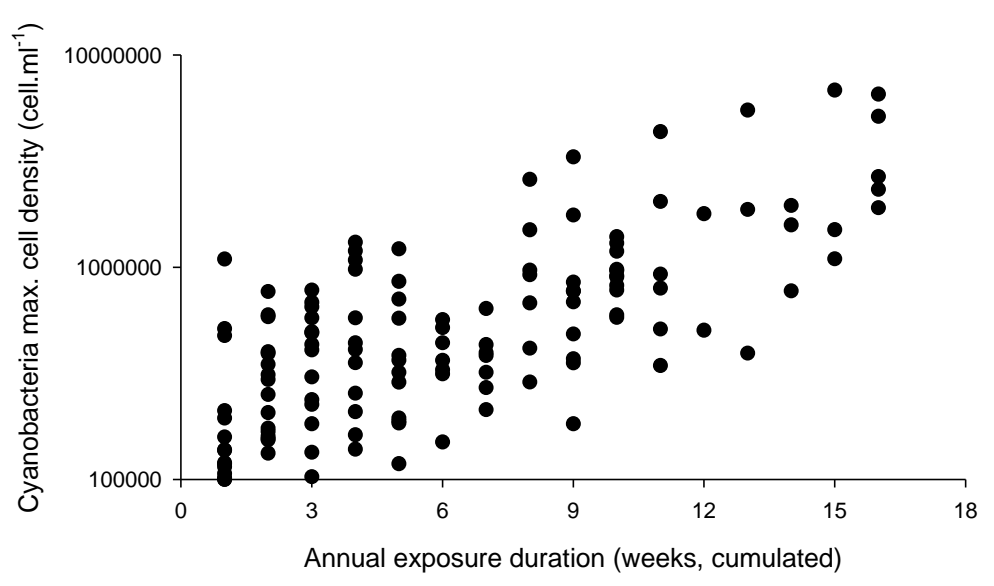

Figure 8

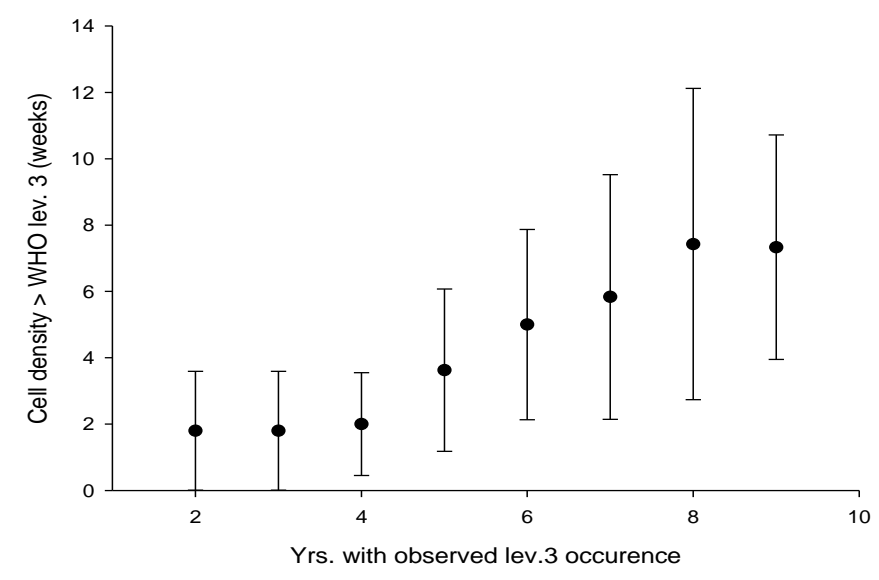


Table 1

\begin{tabular}{|l|c|c|c|}
\hline & Minimum & Maximum & Median \\
\hline Watershed area $\left(\mathrm{km}^{2}\right)$ & 0.2 & 676.0 & 19.6 \\
\hline Lake volume $\left(\mathrm{m}^{3}\right)$ & 20000 & 51000000 & 815700 \\
\hline Maximal depth & 2.0 & 45.0 & 4.1 \\
\hline
\end{tabular}

Table 2

\begin{tabular}{|c|c|l|}
\hline \multirow{4}{*}{ Winter } & Temperature + & Exposure duration favoured vs. cell density \\
\cline { 2 - 3 } & Temperature - & Cell density favoured vs. exposure duration \\
\cline { 2 - 3 } & Sunshine + & Exposure duration favoured vs. cell density \\
\cline { 2 - 3 } & Sunshine - & Cell density favoured vs. exposure duration \\
\hline \multirow{3}{*}{ Summer } & Temperature + & Cell density favoured vs. exposure duration \\
\cline { 2 - 3 } & Temperature - & Exposure duration favoured vs. cell density \\
\cline { 2 - 3 } & Sunshine + & Cell density favoured vs. exposure duration \\
\cline { 2 - 3 } & Sunshine - & Exposure duration favoured vs. cell density \\
\hline
\end{tabular}

